\title{
AN EXPERIMENTAL STUDY ON THE REPAIR OF THE TRAUMATIC LARYNGEAL STENOSIS
}

TAKEO YASHMK, M. D.

Department of Otolaryngology, Faculty of Medicine, University of Hiroshima, Hirosuima (Director: Y. Harada, M. D.)

Laryngeal stenosis was created by partial resection of the thyroid cartilage in dogs. This condition was thought to be compatible with the laryngeal stenosis after acute traumatic injury in man. The laryngeal air space decreased its size to one-third of the normal dog. The thyroid cartilage twisted three months later, but difficulty in breathing was not observed in all dogs. When the defect was covered by perichondrium, cartilage formation observed postoperatively and when the perichondrium was not used, cartilage formation was not observed.

The defects were repaired using auto- or homograft of thyroid or costal cartilage.

All dogs were killed three months after the operation. Perichondrium had to be treated as carefully as possible, because it was useful postoperative cartilage formation. This postoperative cartilage or bone formation occured in the part of the transplantation made the newly created framework stronger. In all cases laryngeal air space was reconstructed satisfactorily.

$$
\text { A83-1017-60714 }
$$

\section{喉頭損傷の再建に関文る奏験的研究}

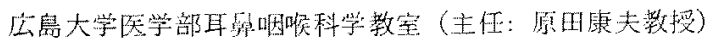

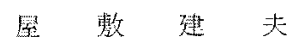

\section{はじめに}

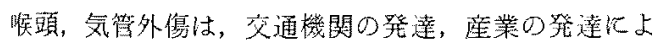

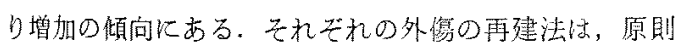

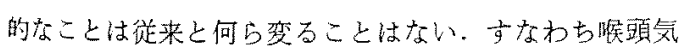

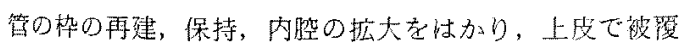

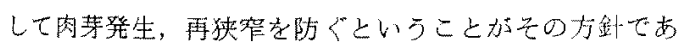
るが，医学の淮歩により成䌙が向上しつつあるがな打渵

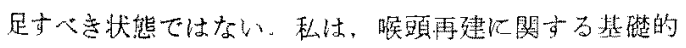

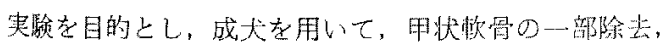
又その除去解分への軟骨移植を行い，再建の状態を篗察 すると同時纪病理学的検索竟行った。

\section{実 酫 方 法}

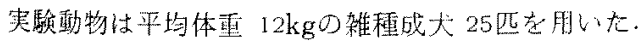

手術化際して麻醉は Nembutal (Pentobarbital sodium)

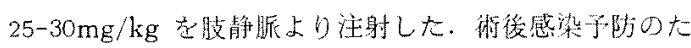
めセフォロスポリン $50 \mathrm{mg} / \mathrm{kg}$ 一邀間筋注した。

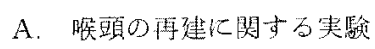

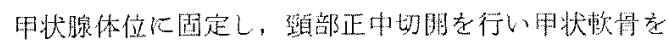

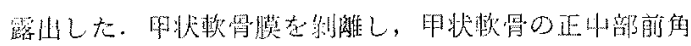

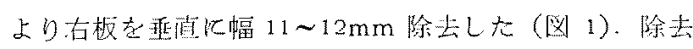

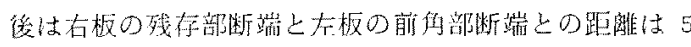

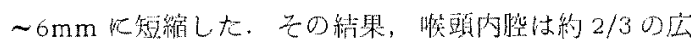

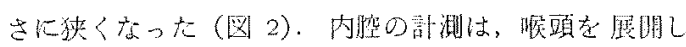

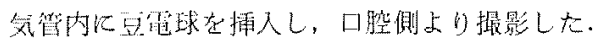

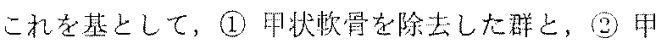

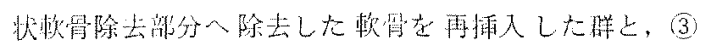

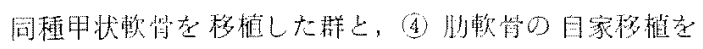


行って，その部分の補充を試みた群の 4 群につき実験 し, 3 个月後に喉頭を取り出し, 甲状㳄骨の形態と移植 部の病理学組織学:的检索を行った.

\section{実 験 成 績}

1.甲状軟骨除去群

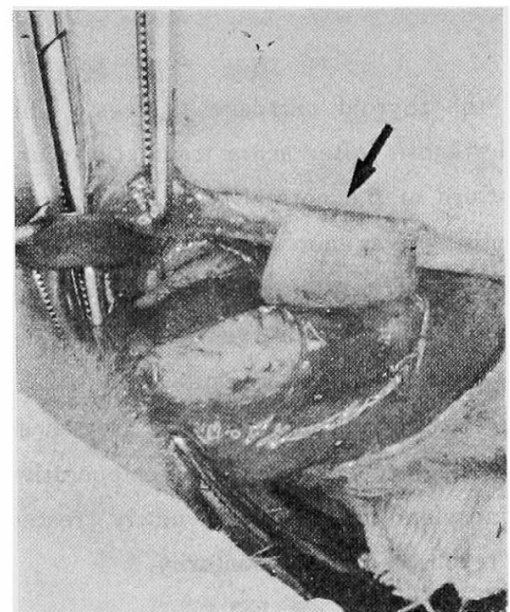

図 1 甲状軟骨の正中部前角より右板を副 $11 \sim 12 \mathrm{~mm}$ に取り出した所（以後右板除 去ということにする)

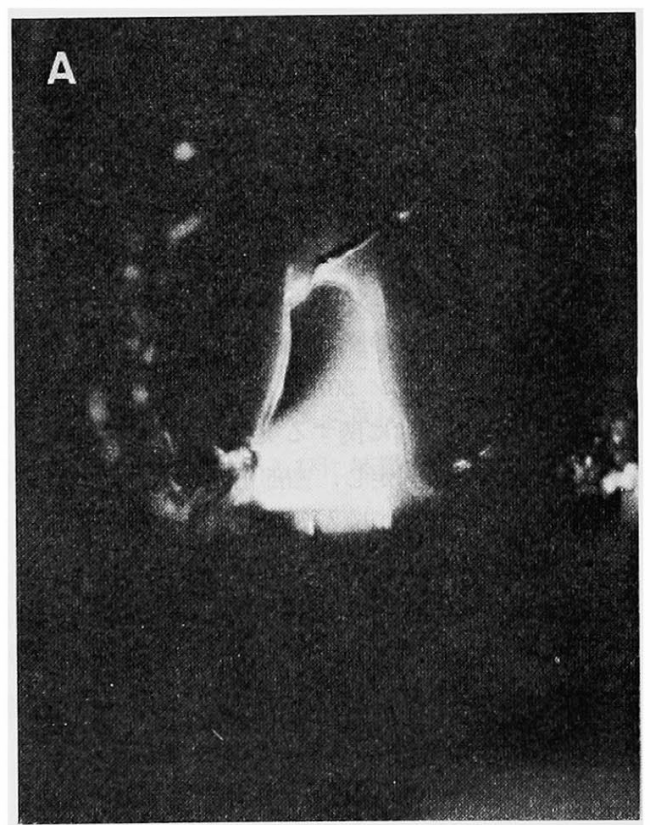

図 2 甲状忺赑·除去術後, 術前の喉䫄内腔 後の声門開大時 甲状軟骨右板除去に上って喉頭内腔は約 $2 / 3$ の広さになった.
甲状軟骨を $11 \sim 12 \mathrm{~mm}$ 除去した場合, 術直後より屠殺 するまでの3 个月後迄，喉頭内腔の狭窄は続いており， ほほその内腔は，術前の $2 / 3$ となった。 また全体の北， 輸状軟骨, 披裂㳄骨との関係は, 甲状軟骨が除去された 方向に短縮し, 捻れを生じ, 啒頭内腔の狭窄を助長して いた.しかし, これでは動物 6 匹とも生存し, 歩行に際 して特別の呼吸困難もなく死亡した例はなかった.

a）甲状軟骨の一部を同様な方法で除去し（図 3), 除 去後の甲状軟骨膜を保存し，これでこの欠損部を覆った 場合には, 軟骨膜より新生軟骨の形成が見られた（図 4). b）㰞骨，軟骨膜とともに除去したものでは，新生軟骨 の师成はその部に認められなかった（図 5,6）.

2.甲状軟省除去部分へ除去した軟骨を再插入した群

a）除去部分へ除去した軟骨を再插入し，銀線で縫合 固定し，甲状軟骨膜で再び覆った場合，3例共甲状軟骨 全体の形態に余り変化をきたさなかった．軟骨接合部は 3个月後では, 新生軟骨の形成がみられ, 甲状軟骨枠は 丈夫な状態となっていた（図 7，8）.

b）甲状軟骨を再㨂入し，固定しても軟骨膜を除去し た場合，右板甲状軟骨断端の外側に挿入軟骨のズレを生 じ，その間に骨形成と軟骨新生が 3 例とも見られた。し かし前角部断端側には，骨形成は見られず，新生軟骨の 形成が認められた。この事実は，技術的操作によるもの

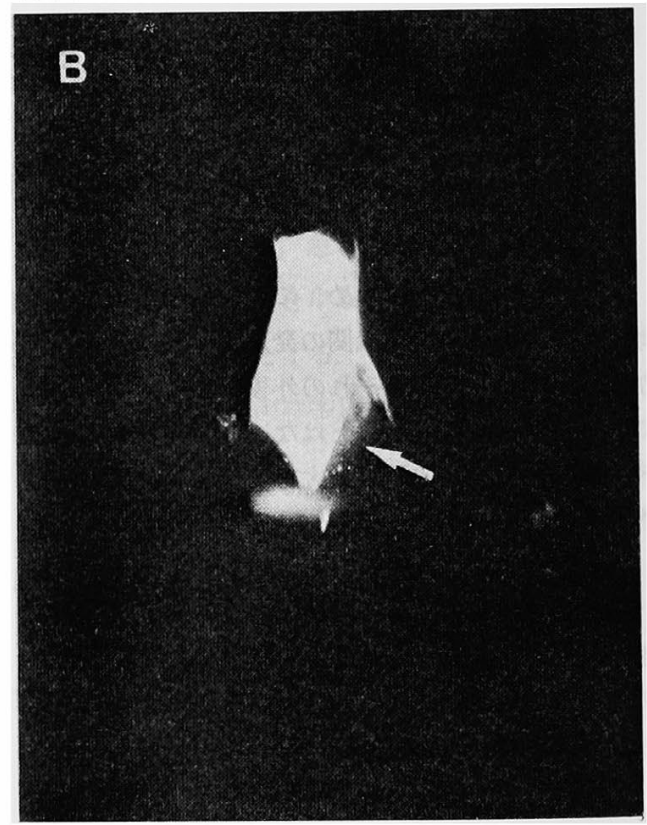

A 正常声門閒大時 B 甲状軟骨除上: 


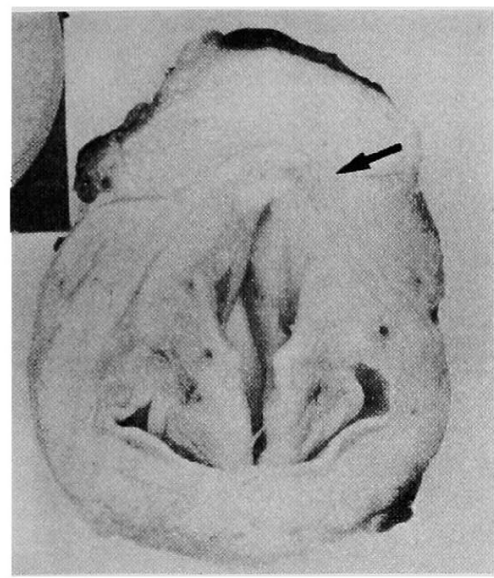

図 3 甲状軟骨右板を除去し軟骨膜で修復 した症例: 術後 3 力月喉頭内腔は狭くな ったが呼吸困難は認めなかった。

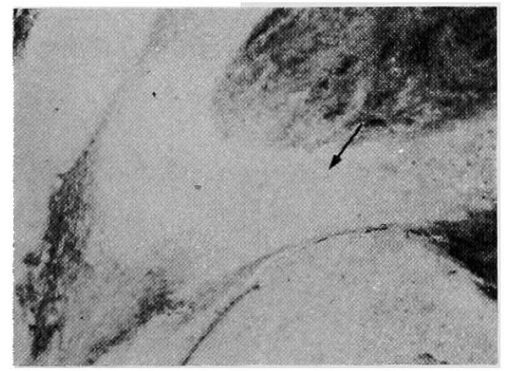

図 4 図 3 の症例の $\mathrm{HE}$ 染色所見: 甲状㳄 骨膜にそって多くの新生軟刑が非成され ている.

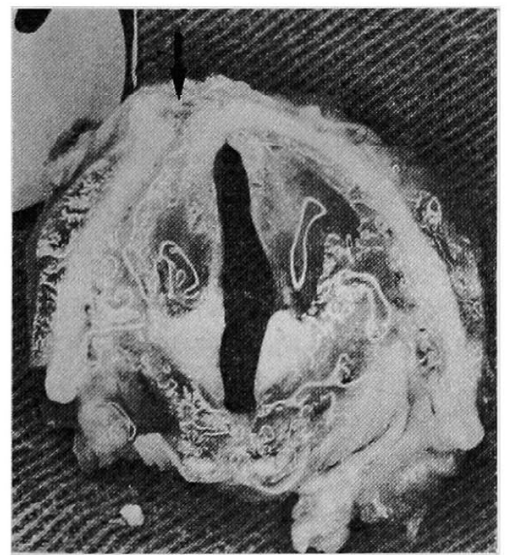

図 5 甲状軟骨右板を除去と軟骨膜を除去 した症例: 術後 3 力月では, 甲状軟骨有 板が除去された方向に短縮し，その部分 飞軟骨形成が認められなかった。

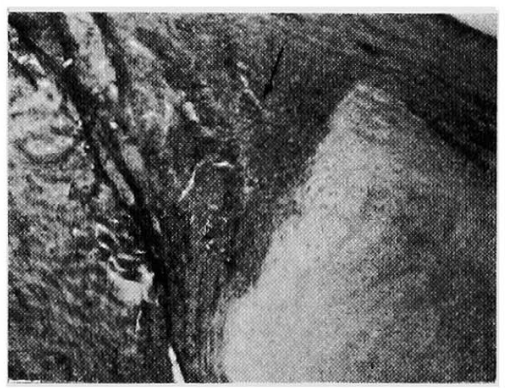

図6図 5 の症例の $\mathrm{HE}$ 染色所見: 右板断 端部に術後 1 力月では新生軟管形成が認 められなかった。

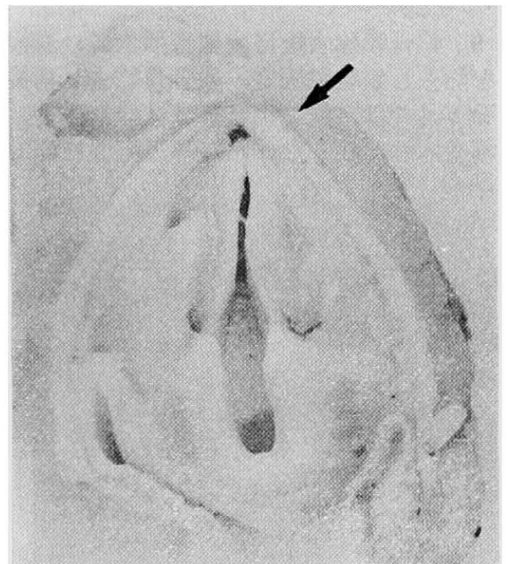

図 7 自家軟骨再捜入群：甲状軟骨膜を䟝 菲し，右板を除去し，もとの状態に再移 值し，銀線で固定し，軟骨膜でその上を 修復し, 術後 3 力月のあので, 㩔頭内腔 は正常に近い状態に保たれた.

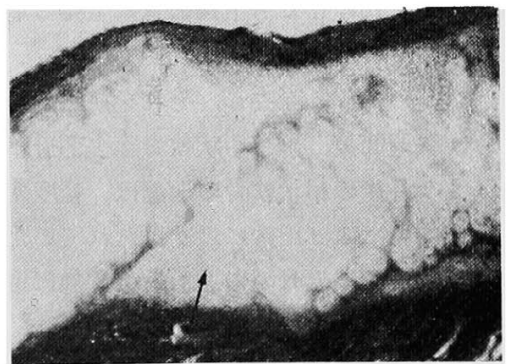

図 8 四7の HE染色所見: 銀線で固定し

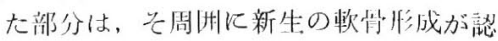
められた。 


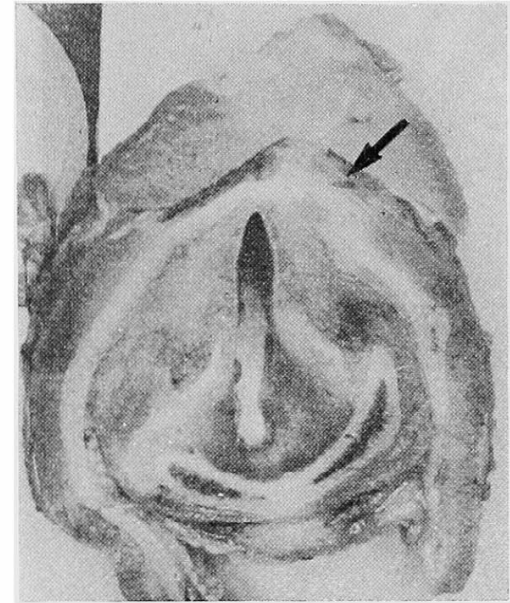

図 9 軟骨膜除去後自家軟骨插入群: 右板 を除去し銀線で固定, 軟骨膜除去し術後 3 力月では, 軟骨接合部にズレを生じ, 喉頭内腔は狭くなったが呼吸困難は伴わ なかった。

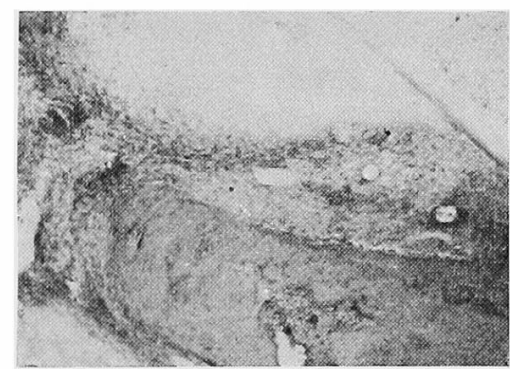

図 10 図9 の軟骨接合部: 特に右板甲状 軟骨断端側の HE染色所見で骨形成と軟 骨形成が認められる。

か，機械的刺激が甲状軟骨の化骨現像を促進したものか 定かで無い。いずれにしても甲状軟骨の全体の形は，ほ ほ正常に復帰していた（図 9, 10).

c）甲状軟骨の一部を除去し，それを前頸部の筋肉内 に埋めこみ, 一週間後, 再び甲状軟骨除去部分へ再捜入 した場合, 3 ケ月後の甲状軟骨の形热は, 軽度变形して いたが，啹頭内㓐はほほ正常に近く保たれていた，この 際，移植㳄骨は，甲状㳄骨の班をもとの状態に復师さす 役割を充分にはたして打り，移植部には，軟骨，骨形成 が著明に珰められ完全に生着していた（図 11，12，13）.

3. 同種甲状㳄胃を移植した群

甲状軟骨の一部を除去したものを，他の犬に同様な操

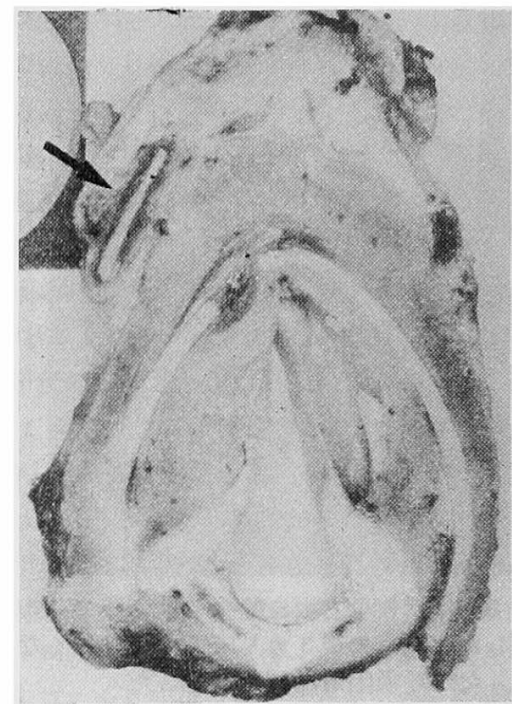

図 11 甲状愽骨右板を除去し, 除去した 軟骨を前頸部筋肉内に埋めこみ術後週 1 間経過したもの.

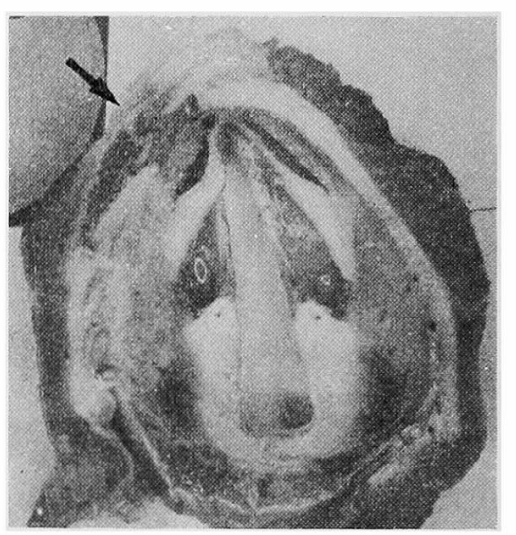

図 12 甲状軟骨右板を除去し，除去した 軟骨を前頸部筋肉内に埋めこみ, 術後 1 週間して, もとの状態飞修復して 3 力月 後のもので, 甲状軟骨の形態は, 軽度変 形していたが, 喉頭内腔はほぼ正常に保 たれ，骨，軟骨形成が認められた。

作を行い移植し銀線で固定した．３ケ月後，3例とも甲 状軟骨の形はほとんど变化なく, 移植軟骨も壤死飞おち いる事なく，移植軟骨の接合部は新生軟骨で扣扣われて いた。また, 一部は結合織で接続され, 骨形成は認めら れなかった. この際, 同種軟骨は完全に生着していた. 従って, 同種の欶骨移植は充分可能であることがわかっ 


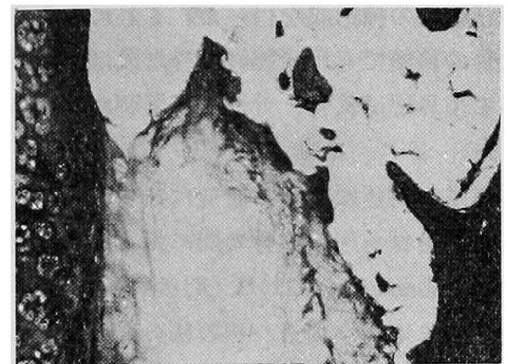

図 13 図 12 の操作した軟骨接合部の HE 染色所見：骨形成，軟骨形成が著明であ る。

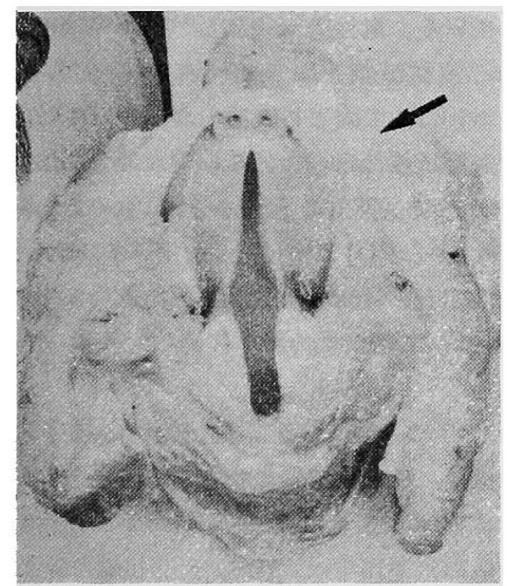

図 14 甲状軟骨右板を除去したものを， 他の犬に同様な操作を行って，同種移植 し, 術後 3 力月のもの: 移植軟骨は生着 し，喉頭内腔はほほ正常に保たれていた。

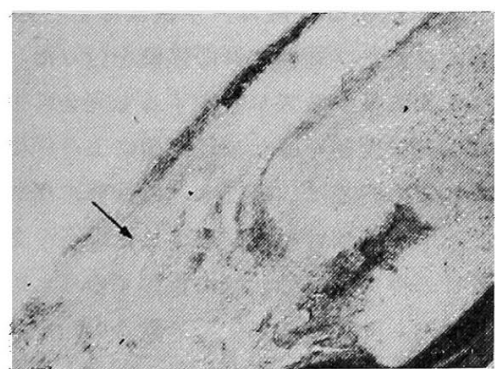

図 15 図 14 のHE 染色所見: 軟骨接合部 に軟骨·形成が認められる。

た（図 14, 15).

4.甲状軟骨除去部分へ肋軟骨の自家移植を行った群 同様な方法で甲状軟骨の一部を除去した部分飞挿入出

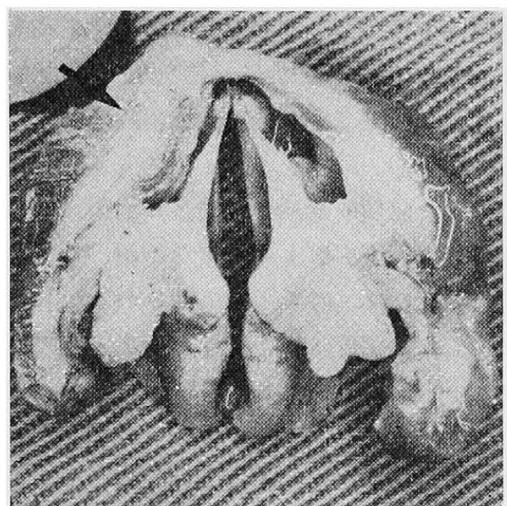

図 16 甲状軟骨右板を除去した所飞, 肋 軟骨を採取し，自家移植し術後 3 力月の もので，甲状㳄骨の形は，ほほ正常の状 態に保たれている.

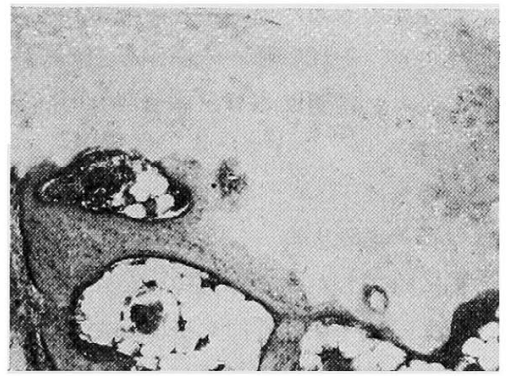

図 17 図16の $\mathrm{HE}$ 染色所見: 助軟骨移植 部分飞骨，軟骨形成が認められ，喉頭の 忰組が夫夫になっていた。

来るように同一動物の肋軟骨を削り，甲状軟骨の形をそ こなわないように銀線で固定した. 3 ケ月後の所見では 手術を行った 2 匹の大の甲状軟骨の形は，正常の状態に 保たれ，接合部に新生軟骨と柽度の骨形成が見られ，肋 軟骨は生着していた（図 16,17）.

以上の如く，甲状軟骨を一部除去し，その部に自家及 び同種軟骨の移植を行った場合は，軟骨移植部に多少の ズレを生ずるも完全に生着した.この結果，喉頭の内腔 はほほ，もとの状態に保たれていた。従って, 甲状軟骨 の枠に变形を生じた場合（外賃等により），まず第一に， 甲状軟骨の枠をもとの状態に整復することが，第一条件 であることがわかった，そのために軟骨の自家，同種軟 骨移植は充分な役割をはたす事がわかった。

考 按

喉頭，気管外傷は，外部からの損傷によるものと，内 


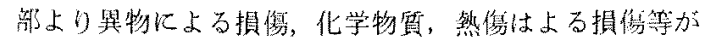

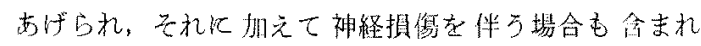

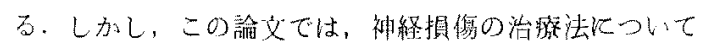
はかれていない。

以上の上うな症例飞遭遇した照合の治撚法恃，急性期

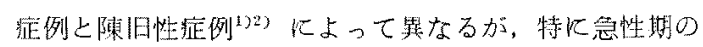
治㾭法が最も大切で, 呼吸困難のための（1）気道の確 保，（2）止血，(3) 支持枠の再建保持吕必要でする。 ? 机でもな括かつ陳旧例に移行するものああれば，普通 （1），(2）《必要な々，(3) 支技枠の再建保持上，(4) 内整の搪大业びに上皮化の促進，(5) 再狭窄防止が必要 上なってくる。

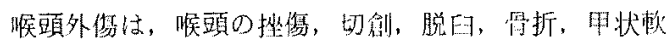

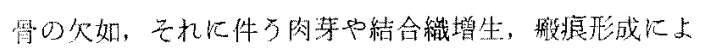
る内腔狭少化があげられる，今回，私は，㩔頭に関する

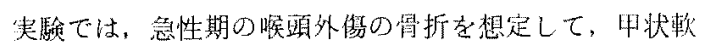

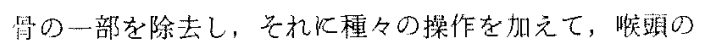

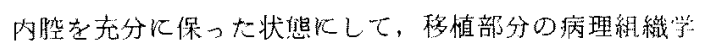
的桢索を行った.

甲状軟骨の操作は

1. 甲状軟骨一部除去群

2.19群汇除去した歌骨を再雨入した群

3.10群に同種甲状軟骨片老移植した群

4. 1 の群仙胁赖骨の自家栘植した群

の如く、4群に分けて夷験を行った，1群の場合は，甲

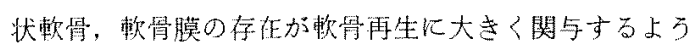
であり，軟学膜があれば，新生軟骨の形成がみられ，悗

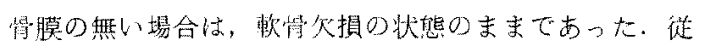
って，急性期外鹪の場合，出来るだけ軟能片並びに甲状

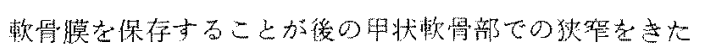
さないようである。

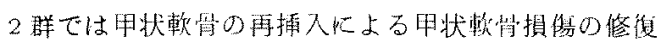
を行った場合を想定したが，粎骨膜を除去しない埸合恃

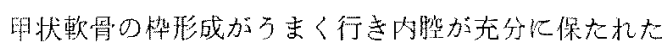

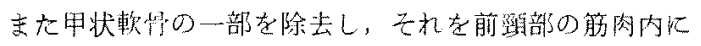
埋めこみ，1週間後何び再㨂入した場合，つまり，受伤

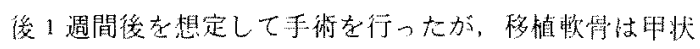

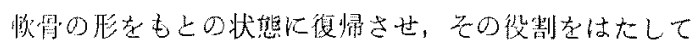

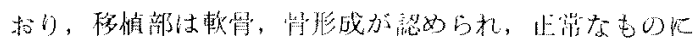

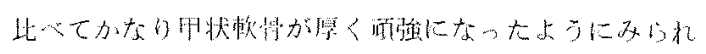
t.

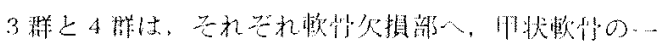

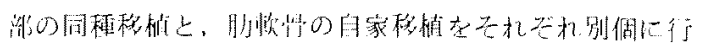

って，甲状㳄骨の枠抢成を行った。これによると自家及 び同種軟骨の移植でむ甲状軟骨の哚形成は，は大されて

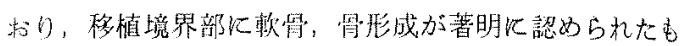
のもあった。

さて，気道の再㠉行関する研究は数多くあり，Looper $(1938)^{3)}$ は，舌骨を忖状吹骨の間に㨉入し甲状軟监の㹡 大をはかり，Fearon $(1972)^{4)}$ は，甲状軟骨の一部を輸

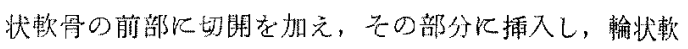
虾部の抎大を猿を用いて实験している。 Ward $(1977)^{5)}$ は. 人で composite hyoid sternohyoidmuscle graft 占門下狭察症例飞用いて成功してい各. Finnegan (1975)

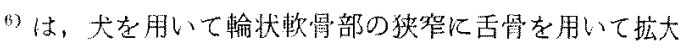
をはかっている、黒住等 $(1975)^{122)}$ は, 甲状禹骨正中で 維简折し，右板が前方に突出している症例老整復後 stainless wire kて固定し成功を拉さめ, また，他の1 例は腸骨を甲状軟骨の右板, 在板の前連合部久損得用い

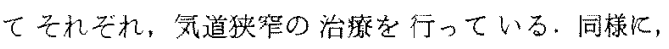
Polayes et al (1970) 728> 屯腸骨を用いて成功している. その他，Lapidot $(1968)^{93}$ は，子豚老用いて甲状軟骨索 flap door にして翰状軟骨部へ移植した実娩を報告して いる。

以上の上うに, 甲状軟骨, 輸状軟骨の損傷, 㹨窄见 壮，杵の保持，应大が赖骨の整復，近くからの軟骨，骨

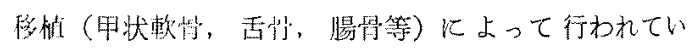
る. その他の気道狭蜜は，瘢痕，肉莱組織の除去，修復， 神経損傷儿対する治療などがあるが、これらの模討はこ の諭文では除外した。

\section{結}

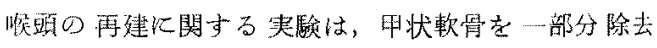
し，その部に自家及び同種軟骨の移植を行った，亮の結 果, 故骨移植部に多少のズレを生するす完全に生着し, 枌組の再建に充分役割老はたし，移植に上り枠組は强附 になった。唤頭の内瀯は、ほほもとの状態に保たれて, 外㑺符によって甲状軟骨の变形が生じた場合，まず第一 に，旧状軟骨の枠をもとの状態整復することが第一条

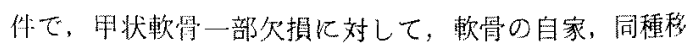
植は允分に役制をはたすことがかかった。 


\section{参考 文献}

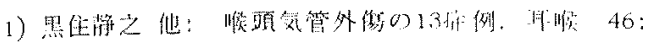
$551-558,1974$.

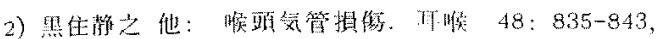
1976.

3) Looper $E A$ : Use of the hyoid bone as a graft in laryngeal stenosis. Arch Otolaryng 28: $106^{-}$ $111,1938$.

4) Fearon $F$ and Cotton $R$ : Surgical Correction of subglottic stenosis of the larynx. - preliminary report of an experimental surgical techniqueAnn Otol 81: 508-513, 1972.

5) Ward $P H$ et al: Composite hyoid sternohyoid muscle grafts in humans. Arch Otolaryng 103: $531-534,1977$

6) Finnegan $D$ A et al: Hyoid autograft repair of chronic subglottic stenosis. Ann Otol 84: $643-$ 649,1975

7) Polayes I M et al: Reconstruction of a stenosed and crushed laryngeal air way. Plast Reconstr Surg 46: $568-571,1970$.

8) Polayes $I M$ et al: Subtotal reconstruction of the human larynx. Transact Amer Acad Ophth \& Otol 75: 56-59, 1971.

9) Lapidot $A$ and Sodagar $R$ et al: Experimental repair of subglottic stenosis in piglets. - Trapdoor Thyrochondroplasty Flap.- Arch Otolaryng $88: 529-535,1968$

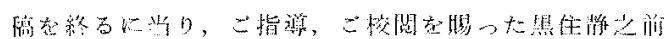

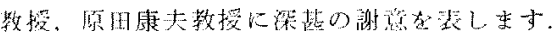

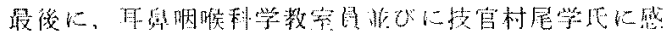
湖いたします。

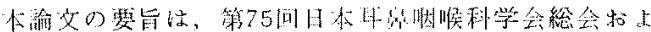

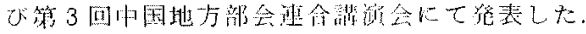

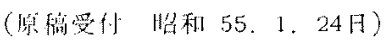

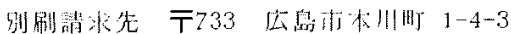

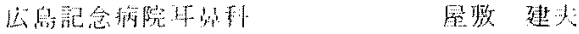

